\title{
Zooplankton and diatoms of temporary and permanent freshwater pans in the Mpumalanga Highveld region, South Africa
}

\author{
Luisa Riato ${ }^{1 *}$, Carin Van Ginkel ${ }^{2} \&$ Jonathan C. Taylor ${ }^{3}$ \\ ${ }^{1}$ Department of Paraclinical Sciences, Faculty of Veterinary Science, University of Pretoria, \\ Private Bag X04, Onderstepoort, 0110 South Africa \\ ${ }^{2}$ Cripsis Environment, 590 20th Avenue, Rietfontein, Pretoria, Gauteng, 0084 South Africa \\ ${ }^{3}$ School of Biological Sciences, North-West University, Private Bag X6001, Potchefstroom, \\ North West Province, 2520 South Africa \\ Received 28 June 2013. Accepted 17 February 2014
}

\begin{abstract}
This paper provides a description of the zooplankton and epiphytic diatom communities of permanent and temporary freshwater pans in the Mpumalanga Highveld region of South Africa. Few studies have investigated the biota of pans in this area, which is seriously threatened by mining and agricultural development. Nineteen pan sites within a $20 \mathrm{~km}$ radius covering a wide range of water chemistries were sampled once for zooplankton, epiphytic diatoms and water physico-chemical data in 2009. Collected zooplankton and diatom samples were identified to species or genus level. Many of the zooplankton taxa reported in this study were not recorded in similar pan studies in South Africa and southern Africa. The study revealed a difference among the compositions of zooplankton and diatom communities between temporary pans and permanent pans. Zooplankton found exclusively in freshwater temporary pans included cladocerans (Megafenestra aurita and Scapholeberis kingi), calanoids (Mesocyclops major and Thermodiaptomus mixtus), a cyclopoid (Acanthocyclops vernalis) and a rotifer (Platyias quadricornis). Permanent pans were characterized by taxa such as cladocerans (Ceriodaphnia rigaudi and Dunhevedia crassa), a calanoid (Metadiaptomus transvaalensis), cyclopoids (Paracyclops fimbriatus and Eucyclops gibsoni) and rotifers (Brachionus dimidiatus and Brachionus plicatilis). The most commonly occurring diatom taxa in temporary pans included taxa indicative of slightly acidic to circumneutral, dystrophic and nutrient-poor waters such as Nitzschia acidoclinata, Gomphonema gracile and Eunotia bilunaris. Permanent pan assemblages were characterized by taxa typical of saline waters, including Nitzschia frustulum, Amphora veneta and Planothidium engelbrechtii. Species of the genera Pinnularia and Eunotia were almost totally absent from permanent pans.
\end{abstract}

Key words: zooplankton, epiphytic diatoms, pans, wetlands, South Africa.

\section{INTRODUCTION}

There has been a growing awareness of the ecological and socioeconomical importance of isolated depressional wetland systems, particularly in Europe, where isolated wetlands have become a priority habitat under the EU Habitats Directive due to their vulnerability to human activities and climate changes (Céréghino et al. 2008). Yet in South Africa, isolated wetlands, which face similar pressures, have largely been ignored. The South African National Water Act (Act No. 36 of 1998) describes the framework which allows for water resource protection and use in a sustainable manner. Within this protection framework provision is made for the assessment of the current ecological integrity or health of a water resource. However the ecological condition of an aquatic habitat

\footnotetext{
*Author for correspondence; E-mail: luisar@wetcs.co.za
}

needs to be ascertained for effective implementation of the National Water Act.

Research activity focusing on isolated depressional wetlands particularly on the topic of biodiversity, has mostly been developed in Europe (Oertli et al. 2009) and North America (Tiner 2003; Lane et al. 2009). In South Africa, such as the Mpumalanga Highveld region, isolated wetlands, locally referred to as pans (the term 'pan' is used hereafter) are exceptionally numerous. However, limnological knowledge of these systems is limited, which is surprising considering their uniqueness in terms of water chemistry, flora and fauna (Hutchinson et al. 1932). For this reason the aim of the present study is to investigate the biological communities of pans in the Mpumalanga Highveld area which are increasingly under threat from mining and agricultural activities. 
Various characteristics of pans in South Africa, including their chemistry and biotic features, have been reviewed (Hutchinson et al. 1932; Seaman et al. 1991; Meintjes et al.1994; Allan et al. 1995). Few studies have focused on macroinvertebrate communities (Day et al. 2010; Ferreira 2012; Bird 2013) and zooplankton taxa (De Roeck et al. 2007; Ferreira 2012) as a tool for biological assessments in temporary and permanent pans in the Western Cape and the Mpumalanga Highveld. Seaman et al. (1991) reported on the ecological characteristics of zooplankton in salt pans in the central and western regions of South Africa as well as the Mpumalanga Highveld. However, there is still little known about the zooplankton communities of pans in South Africa and considerably less information available on diatom distribution and diversity in these systems.

Diatoms have a long history of use in the assessment of inland waters internationally as they account for the highest number of species among the primary producers in aquatic systems and respond rapidly to a wide range of toxicants (Pan et al. 1999; U.S. EPA 2001). Zooplankton taxa have different preferences for trophic state and water clarity and are known to vary predictably with wetland quality and respond quickly to changes in the environment (Lougheed \& Chow-Fraser 2002).

The only comprehensive investigation of depressional wetlands in the Mpumalanga Highveld area, including zooplankton and diatom species, is that by Hutchinson et al. (1932) who provided an ecological study of a variety of temporary and permanent pans in the area. Taxonomic identification of diatoms was mostly undetermined. Nevertheless the study highlighted the diversity and complexity of temporary pans, which previous studies have shown to be partly attributable to the variability in length of hydroperiod (Gaiser \& Johansen 2000; Dimitriou et al. 2009). It is therefore essential to examine the characteristics that define these highly variable systems in order to distinguish changes in biological communities caused by human disturbances from natural variations. This is particularly vital in an area such as the Mpumalanga Highveld where pans are under severe pressure as a result of land cover conversion.

This study has largely been driven by the need for ecological information on South African inland pans in order to assess the ecological status of this type of water body more effectively in accordance with the National Water Act and perhaps provide insight into similar waterbodies internationally.
The main purpose of this paper is to report on species of diatoms and zooplankton from pans in the Mpumalanga Highveld region since very little previous taxonomic or ecological records are available on such flora and fauna.

\section{MATERIALS \& METHODS}

\section{Study area}

The study was carried out in the Highveld region of the Mpumalanga Province, host to one of the densest clusters of pans in South Africa. The region is at an altitude of approximately $1700 \mathrm{~m}$ with minimum temperatures below $0^{\circ} \mathrm{C}$ in the winter and average annual rainfall of $c .706 \mathrm{~mm}$. Geology generally consists of weakly cemented sandstones and fissile shales of the Karoo Supergroup with some intrusion by highly resistant dolerite sills and dykes (Tooth \& McCarthy 2007). In the grasslands of Mpumalanga, pans typically receive direct rainfall as well as generally diffuse flow entering the pans through seepage through the surrounding soil mass, and/or groundwater (Tooth \& McCarthy 2007).These depressions are shallow, and even when fully inundated, are usually less than $3 \mathrm{~m}$ deep. These are usually circular to oval in shape (Goudie \& Thomas 1985), and where two or more depressions have spread and combined, they form characteristically kidney-shaped or lobed wetlands. These systems are highly variable in terms of vegetation, size and above all water chemistry whilst being in close proximity to one another. The pans vary from permanently inundated reed pans characterized by a central, emergent Phragmites australis reedbed, surrounded by a ring of open water underlain with submergent macrophytes, such as Lagarosiphon sp. and Potamogeton sp., to temporarily inundated grass pans covered by grasses and sedges, often dominated by floating mats of Leersia hexandra (Allan et al. 1995). Typically found on the outermost margins are crops of maize and occasionally a few alien tree species (Eucalyptus sp., Salix sp., Acacia sp.).

Over a period of two days in May 2009, 11 temporary and eight permanent pans (range $=$ 6-213 ha, Fig. 1) were sampled in a $20 \mathrm{~km}$ radius once for zooplankton, epiphytic diatoms and water chemistry where feasible. Further site information is given in Table 1. All sites are situated in a heavily transformed landscape which has been subject to strong alterations due to land use conversions, namely mining and agriculture. Sites 


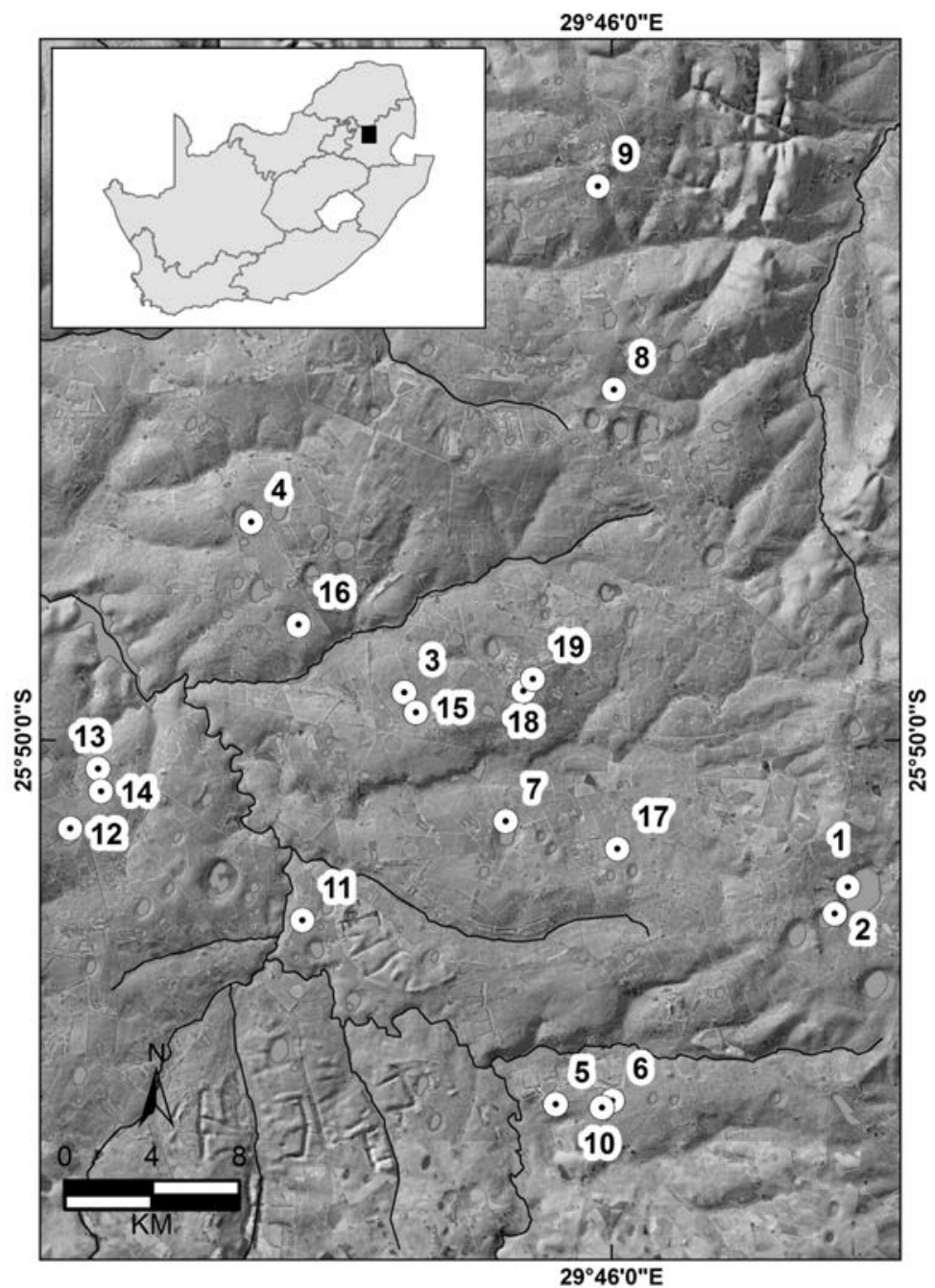

Fig. 1. Study area and location of sampling sites.

were randomly selected using 1:50 000 scale South African topographical maps and GIS software, and later ground-truthed to establish the wetland type in terms of hydrological regime (temporary or permanently inundated wetlands).

Sample collection, preparation and analysis

Zooplankton samples were collected using a plankton net ( $150 \mu \mathrm{m}$ mesh size) to make horizontal tows of $10 \mathrm{~m}$ length from the margin of the pan to the centre. Captured zooplankton were preserved in $70 \%$ ethanol and identified using the highest taxonomic resolution possible (usually species or genus). The cladocerans were identified to species level according to Day et al. (1999). Ostracods and copepods were identified using
Day et al. (2001), and the rotifers according to Ahlstrom (1940), Pennak (1978), Thorp \& Covich (1991) and Day \& de Moor (2002).

Epiphytic diatoms were sampled by randomly selecting submersed plants from the wetland (water depth $<1 \mathrm{~m}$ ) according to methods described by Lane \& Brown (2007). Samples were preserved in ethanol and kept at $4^{\circ} \mathrm{C}$ until analyses. Water samples were obtained simultaneously with the diatom samples and analysed for conductivity, $\mathrm{pH}, \mathrm{CO}_{3}{ }^{-}, \mathrm{HCO}_{3}{ }^{-}, \mathrm{Ca}^{2+}, \mathrm{PO}_{4}{ }^{3-}, \mathrm{Mg}^{2+}, \mathrm{NO}_{3}{ }^{-}$, $\mathrm{NO}_{2}^{-}, \mathrm{K}^{+}, \mathrm{Na}^{+}, \mathrm{SO}_{4}{ }^{2-}, \mathrm{Cl}^{-}$at the Agricultural Research Council's laboratory in Pretoria following standard procedures (APHA 1998).

Diatoms were prepared by oxidizing organic material in samples with hydrochloric acid and 


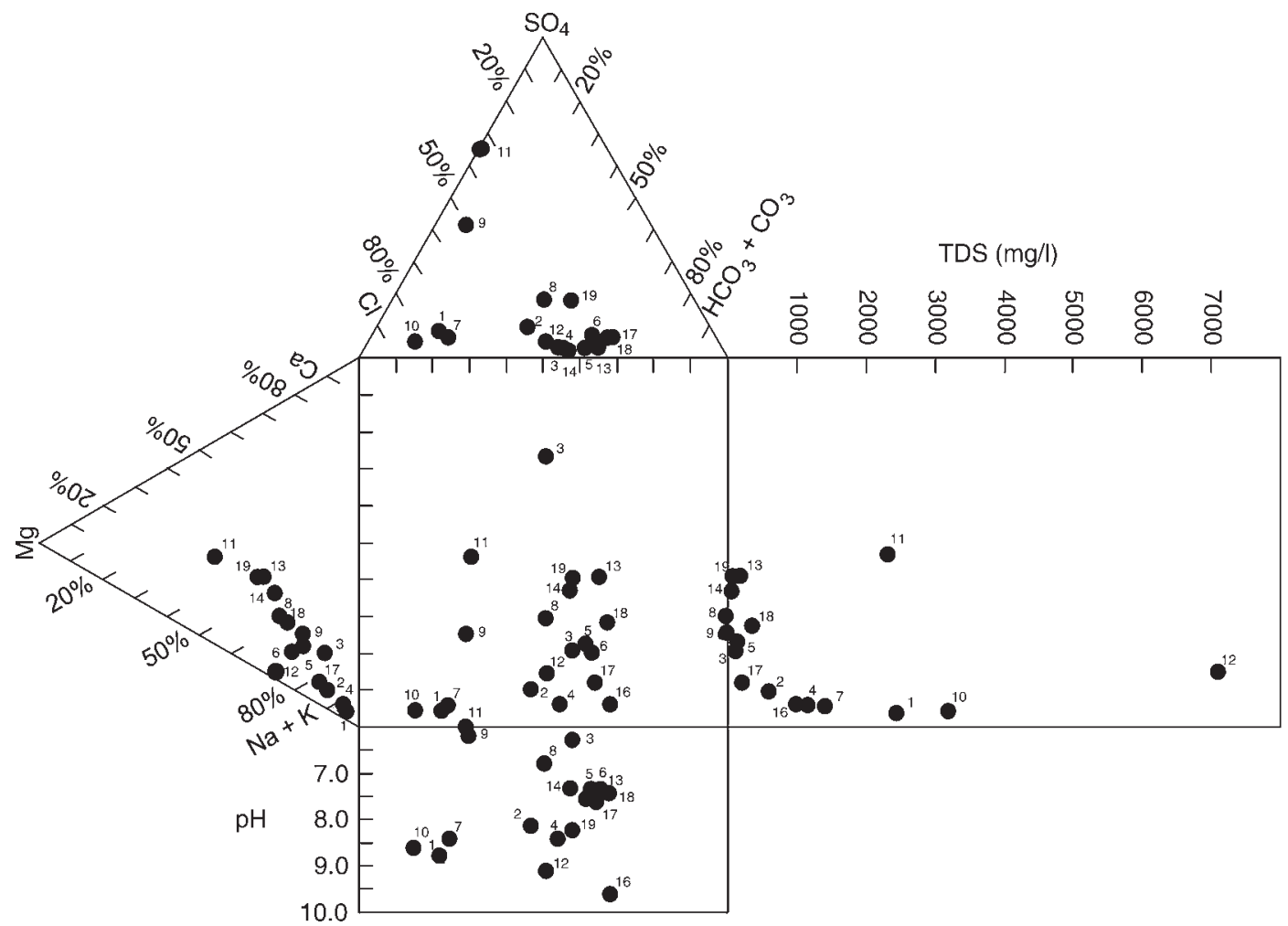

Fig. 2. Durov diagram showing ionic composition, $\mathrm{pH}$ and total dissolved solids for the Mpumalanga Highveld pan dataset.

potassium permanganate. Clean diatom frustules were mounted in a synthetic resin with high refraction index (1.73) and at least 400 valves were counted and identified to the lowest taxonomic level possible (usually species) using a light microscope with $\times 1000$ magnification. The main diatom floras used for taxonomic identification were Archibald (1966), Gasse (1986) and Krammer \& Lange-Bertalot (1986-1991). All diatom materials are housed in the South African Diatom Collection (SADC) of the Research Unit for Environmental Sciences and Management, North-West University, South Africa. Zooplankton voucher specimens are deposited in the Life Sciences Museum and Biodiversity Centre, University of the Witwatersrand.

\section{RESULTS \& DISCUSSION}

\section{Environmental characteristics of sites}

The 18 pan sites analysed for water chemistry cover a large environmental gradient. Results are summarized in Table 1. At the time of sampling there was less than $1 \mathrm{~cm}$ of water at Site 15 , there- fore it was not feasible to collect a water sample for chemical analysis. Fig. 2 shows the distribution of pans based on their ionic composition, $\mathrm{pH}$ and total dissolved solids. With the exception of sites 11 and 12, the pan dataset are of either sodium-chloride or sodium-bicarbonate composition, ranging in conductivity from $10 \mathrm{mS} / \mathrm{m}$ to $931 \mathrm{mS} / \mathrm{m}$. High sodium and chloride concentrations may reflect the marine origins of the bedrocks. The pans are composed of almost equal amounts of calcium and magnesium, reflecting the dolomitic origin of the water with $\mathrm{pH}$ ranges from 6.0 to 9.7. High $\mathrm{pH}$ values may reflect the dolomitic character of the groundwater. Low $\mathrm{pH}$ values may reflect acidic impacts of anthropogenic origin. Clear outliers in the dataset are Site 11 dominated by sulphate ions and Site 12 by potassium ions whose chemical composition is clearly different from the other pans in the dataset and are thought to reflect impacts from mining and intensive agricultural practices.

\section{Species composition of zooplankton}

Zooplankton was sampled from 12 pan sites. 
Of these sites five are temporary water bodies, while seven are permanent systems. A total of 34 zooplankton species belonging to 21 genera were identified (Appendix 1). The highest diversity recorded amongst pans in the current study was found at Site 17 (17 taxa) and 18 (15) which are both freshwater temporary pans (conductivities $<100 \mathrm{mS} / \mathrm{m}$ ) of sodium-bicarbonate type. The lowest diversity was found at sites 1 (3) and 10 (4) which are highly saline, permanent pans of sodium-chloride type impacted by nutrients from intensive agriculture in the area as shown in Table 1. Species tolerant of such high salinities included Lovenula falcifera and Metadiaptomus transvaalensis. These taxa have previously been described as the most common copepods in southern African salt pans (up to $\sim 7800 \mathrm{mg} / 1 \mathrm{Na}$, $\sim 9000 \mathrm{mg} / \mathrm{l} \mathrm{Cl}$ ) but have also been reported in a variety of only slightly saline to quite fresh waterbodies (Seaman et al. 1991).

Taxa that were found exclusively in temporary freshwater pans were the Cladocera species Megafenestra aurita, Scapholeberis kingi, Daphnia laevis and Daphnia pulex, the Calanoida species Mesocyclops major and Thermodiaptomus mixtus, the Cyclopoida Acanthocyclops vernalis, Type A and G Cyprididae and the Rotifera Platyias quadricornis and a Mytilina sp.

A large number of the species present were found in a range of freshwater to very saline conditions. The cosmopolitan Cyclopoida species Ectocyclops phaleratus was found most commonly at 10 of the 12 sites. It occurs in small pans, is acidsensitive and does not occur in waters with $\mathrm{pH}$ below 6 (Haney 2013). The most common of the Calanoida species was Metadiaptomus transvaalensis found at 9 of the 12 sites and the Cladocera species which occurred most frequently was Simocephalus vetulus, a cosmopolitan species known from littoral habitats.

Species that can tolerate highly saline conditions, as were found at Site 12, are the Cladocera species, Ceriodaphnia rigaudi, an Alona sp., Dunhevedia crassa and Macrothrix spinosa, the Calanoida, Metadiaptomus transvaalensis and the Cyclopoida, Paracyclops fimbriatus, Eucyclops gibsoni and Ectocyclops phaleratus. The Rotifera found under very saline conditions were Brachionus dimidiatus and Brachionus plicatilis. B. plicatilis was reported in salt pans in the Free State and Tswaing Crater (formerly known as Pretoria Salt Pan) as well as inland saline waters across southern Africa (Seaman et al. 1991).

Many of the zooplankton taxa reported in this study were not recorded in similar pan studies in southern Africa. There was little compositional overlap between the zooplankton species recorded in the permanent pans in this study and that of various permanent pans sampled in the same region by Hutchinson et al. (1932) and Ferreira et al. (2012). The species which were comparable included Ceriodaphnia reticulate, Ceriodaphnia rigaudi, Daphnia laevis, Lovenula falcifera, Metadiaptomus transvaalensis, Platyias quadricornis, Pseudocypris expansa, Pseudocypris spinosa and Simocephalus vetulus. Platyias quadricornis, Ceriodaphnia rigaudi, Lovenula falcifera and Pseudocypris expansa were also recorded in temporary pans located east of the Mpumalanga Highveld area in the Gauteng Province (Hutchinson et al. 1932). Other similar species present in the temporary pans in this study and those studied by Hutchinson et al. (1932) included Brachionus quadridentatus, Chydoris sphaericus and Daphnia barbata.

Few species overlapped with the zooplankton taxa recorded from various saline waters in South Africa and southern Africa reported by Seaman et al. (1991), those being Lovenula falcifera, Metadiaptomus transvaalensis and Brachionus plicatilis. These results highlight the large variation of zooplankton communities amongst temporary and permanent pans and underline the need for further studies on the diversity and distribution of pan zooplankton communities locally and throughout southern Africa.

\section{Diatom distribution}

A total of 140 species of epiphytic diatoms belonging to 37 main zoological groups were identified (Appendix 2). Of these, 61 taxa were unique to one site and 24 taxa found at only two sites. The genus Nitzschia contained the rarest taxa (19). Genera represented by the greatest number of taxa were Nitzschia (32), Navicula (17), Gomphonema (11) and Eunotia (11). Some of the taxa were widespread (7 taxa were found in $>50 \%$ of sites) namely Gomphonema parvulum (16 sites), Nitzschia frustulum (12 sites), Nitzschia palea (12 sites), Gomphonema gracile (11 sites), Eunotia bilunaris (11 sites), Nitzschia acidoclinata (11 sites) and Nitzschia palea var. debilis (10 sites). The diatom assemblages resemble those in a study by Lane and Brown (2007) who investigated the epiphytic assemblage composition in numerous pans in Florida, U.S.A. Gomphonema parvulum and Nitzschia palea are considered eutrophic indicators (Van Dam et al. 1994; McCormick \& Stevenson 
1998) and it is therefore not surprising that these taxa were prevalent throughout the study pans which receive high nutrient and organic inputs as a result of intensive agricultural practices.

The most commonly occurring taxa in temporary pans (except for Site 11 which was sulphatecontaminated), included taxa indicative of slightly acidic to circumneutral, dystrophic and nutrientpoor waters such as Nitzschia acidoclinata, Gomphonema gracile and Eunotia bilunaris. These seasonally inundated systems prone to episodic drying also contained a diverse assemblage of aerophilic taxa such as Pinnularia borealis, Pinnularia subcapitata, Luticola mutica and Hantzschia amphioxys. Such taxa can grow in, or endure drought-prone, low-moisture environments (Lowe \& Collins 1973). In contrast, frequent taxa occurring in permanent pans comprised Nitzschia frustulum, Amphora veneta and Planothidium engelbrechtii, taxa often associated with saline waterbodies (Cholnoky 1955; Krammer \& Lange-Bertalot 1986; 1988). Species of the genera Pinnularia and Eunotia were almost totally absent from permanent pans.

This study provides a checklist of freshwater zooplankton and diatoms sampled within a variety of pans which encompass a broad range of hydrologic characteristics. The results contribute to a better knowledge of the richness and composition of zooplankton and epiphytic diatom species in pans in the Mpumalanga Highveld region. This is particularly vital in an area where pans are little studied and under serious threat as a result of environmental modifications and land cover conversion. Future research is required to identify zooplankton and diatom community indicators useful to evaluate the effect of anthropogenic impacts on freshwater pans in the Mpumalanga Highveld region.

\section{ACKNOWLEDGEMENTS}

The collection and analysis of the diatom dataset used in this study has been supported by Mafube Mining (Pty) Ltd. Our thanks go to Scott Driskill of Wetland Consulting Services (Pty) Ltd who provided logistical and field support. We are most grateful to Marie Watson at the University of the Free State for her help in zooplankton identification and James du G. Harrison at the Life Sciences Museum and Biodiversity Centre, University of Witwatersrand, for cataloging the zooplankton specimens. We also thank Peter Wade of Envirodyn Strategies CC and Gina Walsh from Ecotone Freshwater Consultants for their valuable advice.

\section{REFERENCES}

ARCHIBALD, R.E.M. 1966. Some new and rare diatoms from South Africa. In: Nova Hedwigia, (eds) J. Gerloff, F.Mattick \& J. Poelt, 1st edn, pp. 253-269. J. Cramer, Lehre, Germany.

AHLSTROM, E.H. 1940. A revision of the Rotatorian genera Brachionus and Platyias with descriptions of one new species and two new varieties. Bulletin of the American Museum of Natural History 77(3): 143-184.

ALLAN, D.G., SEAMAN, M.T. \& KALETJA. B. 1995. The endoheric depression wetlands of South Africa. In: Wetlands of South Africa, (ed.) G.I. Cowan, 1st edn, pp. 75-101. South African Wetlands Conservation Programme Series, Department of Environmental Affairs and Tourism, Pretoria.

AMERICAN PUBLIC HEALTH ASSOCIATION (APHA). 1998. Standard Methods for the Examination of Water and Wastewater. American Public Health Association, Washington, DC.

BIRD, M.S., MLAMBO, M.C. \& DAY, J.A. 2013. Macroinvertebrates as unreliable indicators of human disturbance in temporary depression wetlands of the south-western Cape, South Africa. Hydrobiologia 720: 19-37.

CÉRÉGHINO, R., BIGGS, J, OERTLI, B. \& DECLERCK, S. 2008. The ecology of European ponds: defining the characteristics of a neglected freshwater habitat. Hydrobiologia 597: 1-6.

CHOLNOKY, B.J. 1955. Diatomeen aus salzhaltigen Binnen-gewässern der westlichen Kaap-Provinz in Südafrika. Sonderabdruck aus den Berichten der Deutschen Botanischen Gesellschaft 68(1): 11-23.

DAY, J.A., STEWART, B.A., DE MOOR, I.J. \& LOUW, A.E. 1999. Guides to the Freshwater Invertebrates of Southern Africa. Volume 2: Crustacea I. Notostraca, Anostraca, Conchostraca and Cladocera. Water Research Commission Report TT121/00, Water Research Commission, Pretoria.

DAY, J.A., STEWART, B.A., DE MOOR, I.J. \& LOUW, A.E. 2001. Guides to the Freshwater Invertebrates of Southern Africa. Volume 4: Crustacea III. Bathynellacea, Amphipoda, Isopoda, Spelaeogriphacea, Tanaidacea and Decapoda. Water Research Commission Report TT141/01, Water Research Commission, Pretoria.

DAY, J.A. \& DE MOOR, I.J. 2002. Guides to the Freshwater Invertebrates of Southern Africa. Volume 5: Non-Arthropods. The Protozoans, Porifera, Cnidaria, Platyhelminthes, Nemertea, Rotifera, Nematoda, Nematomorpha, Gastrotrichia, Bryozoa, Tardigrada, Polychaeta, Oligochaeta and Hirudinea. Water Research Commission Report TT167/02, Water Research Commission, Pretoria.

DAY, J., DAY, E., ROSS-GILLESPIE, V. \& KETLEY, A. 2010. The Assessment of Temporary Wetlands during Dry Conditions. Water Research Commission Report TT434/ 09, Water Research Commission, Pretoria.

DE ROECK, E.R., VANSCHOENWINKEL, B.J., DAY, J.A., XU, Y., RAITT, L. \& BRENDONCK, L. 2007. Conservation status of large branchipods in the Western Cape, South Africa. Wetlands 27: 162-173.

DIMITRIOU, E., MOUSSOULIS, E., STAMATI, F. \& NIKOLAIDIS, N. 2009. Modelling hydrological characteristics of Mediterranean temporary pans and 
potential impacts from climate change. Hydrobiologia 634: 195-208.

FERREIRA, M., WEPENER, V. \& VAN VUREN, J.H.J. 2012. Aquatic invertebrate communities of perennial pans in Mpumalanga, South Africa: a diversity and functional approach. African Invertebrates 53(2): 751768.

GAISER, E.E. \& JOHANSEN, J. 2000. Freshwater diatoms from Carolina Bays and other isolated wetlands on the Atlantic coastal plain of South Carolina, U.S.A., with descriptions of seven taxa new to science. Diatom Research 15(1): 75-130.

GASSE, F. 1986. East African Diatoms. Taxonomy, ecological distribution. Bibliotheca Diatomologica, Vol. 11. J. Cramer, Stuttgart.

GOUDIE, A.S. \& THOMAS, D.S.G. 1985. Pans in southern Africa with particular reference to South Africa and Zimbabwe. Zeitschrift für Geomorphologie 29: 1-19.

HANEY, J.F. 2013. An image-based key to the zooplankton of North America. Version 5.0. University of New Hampshire Center for Freshwater Biology. Electronic database Online at: http://cfb.unh.edu/cfbkey/html/ index.html (accessed 3 June 2013).

HUTCHINSON, G.E., PICKFORD, G.E. \& SCHUURMAN, J.F.M. 1932. A contribution to the Hydrobiology of depression wetlands and other inland waters of South Africa. Archive für Hydrobiologie 24: $1-154$.

KRAMMER, K. \& LANGE-BERTALOT, H. 1986-1991. Süßwasserflora von Mitteleuropa. Bacillariophyceae. 2/1-2/4. Fischer, Stuttgart.

LANE, C.R. \& BROWN, M.T. 2007. Diatoms as indicators of isolated herbaceous wetland condition in Florida, U.S.A. Ecological Indicators 7: 521-540.

LANE, C.R., REISS, K.C., DE CELLES, S. \& BROWN, M.T. 2009. Benthic diatom composition in isolated forested wetlands subject to drying: implications for monitoring and assessment. Ecological Indicators 9(6): $1121-1128$.

LOUGHEED, V.L. \& CHOW-FRASER, P. 2002. Development and use of a zooplankton index of wetland quality in the Laurentian Great Lakes basin. Ecological Applications 12(2): 474-486.

LOWE, R. L. \& COLLINS, G.B. 1973. An aerophilous dia- tom community from Hocking County, Ohio. Transactions of the American Microscopical Society 92: 492-496.

McCORMICK, P.V. \& STEVENSON, R.J. 1998. Periphyton as a tool for ecological assessment and management in the Florida Everglades. Journal of Phycology 34: 726-733.

MEINTJES, S., SEAMAN, M.T. \& KOK, D.J. 1994. Duration of inundation and change in physical and chemical characteristics of small temporary depression wetlands in South Africa. Hydrobiologia 281(2): 79-90.

OERTLI, B., CEREGHINO, R., HULL, A. \& MIRACLE, R. 2009. Pan conservation: From science to practice. Hydrobiologia 634: 1-9.

PAN, Y.D., STEVENSON, R.J., HILL, B.H., KAUFMANN, P.R. \& HERLIHY, A.T. 1999. Spatial patterns and ecological determinants of benthic algal assemblages in Mid-Atlantic streams, U.S.A. Journal of Phycology 35: 460-468.

PENNAK, R.W. 1978. Freshwater Invertebrates of the United States. Johan Wiley and Sons, New York.

RSA. 1998. National Water Act No. 36 of 1998. Government Gazette. No. 19182. Government Printer, Pretoria.

SEAMAN, M.T., ASHTON, P.J. \& WILLIAMS, W.D. 1991. Inland salt waters of southern Africa. Hydrobiologia 210: 75-91.

THORP J.H. \& COVICH A.P. 1991. Ecology and Classification of North American Freshwater Invertebrates. Academic Press, London.

TINER, R.W. 2003. Geographically isolated wetlands of the United States. Wetlands 23(3): 494-516.

TOOTH, S. \& McCARTHY, T.S. 2007. Wetlands in drylands: geomorphological and sedimentological characteristics, with emphasis on examples from southern Africa. Progress in Physical Geography 31(1): 3-41.

U.S. ENVIRONMENTAL PROTECTION AGENCY (EPA). 2001. Indicators for monitoring biological integrity of inland, freshwater wetlands. EPA-843-R-01. Office of Water Wetlands Division, Washington, DC.

VAN DAM, H., MERTENS, A. \& SINKELDAM, J. 1994. A coded checklist and ecological indicator values of freshwater diatoms from the Netherlands. Netherlands Journal of Aquatic Ecology 28(1): 117-133.

Responsible Editor: D. Pillay 
Riato et al.: Zooplankton and diatoms of freshwater pans in Mpumalanga

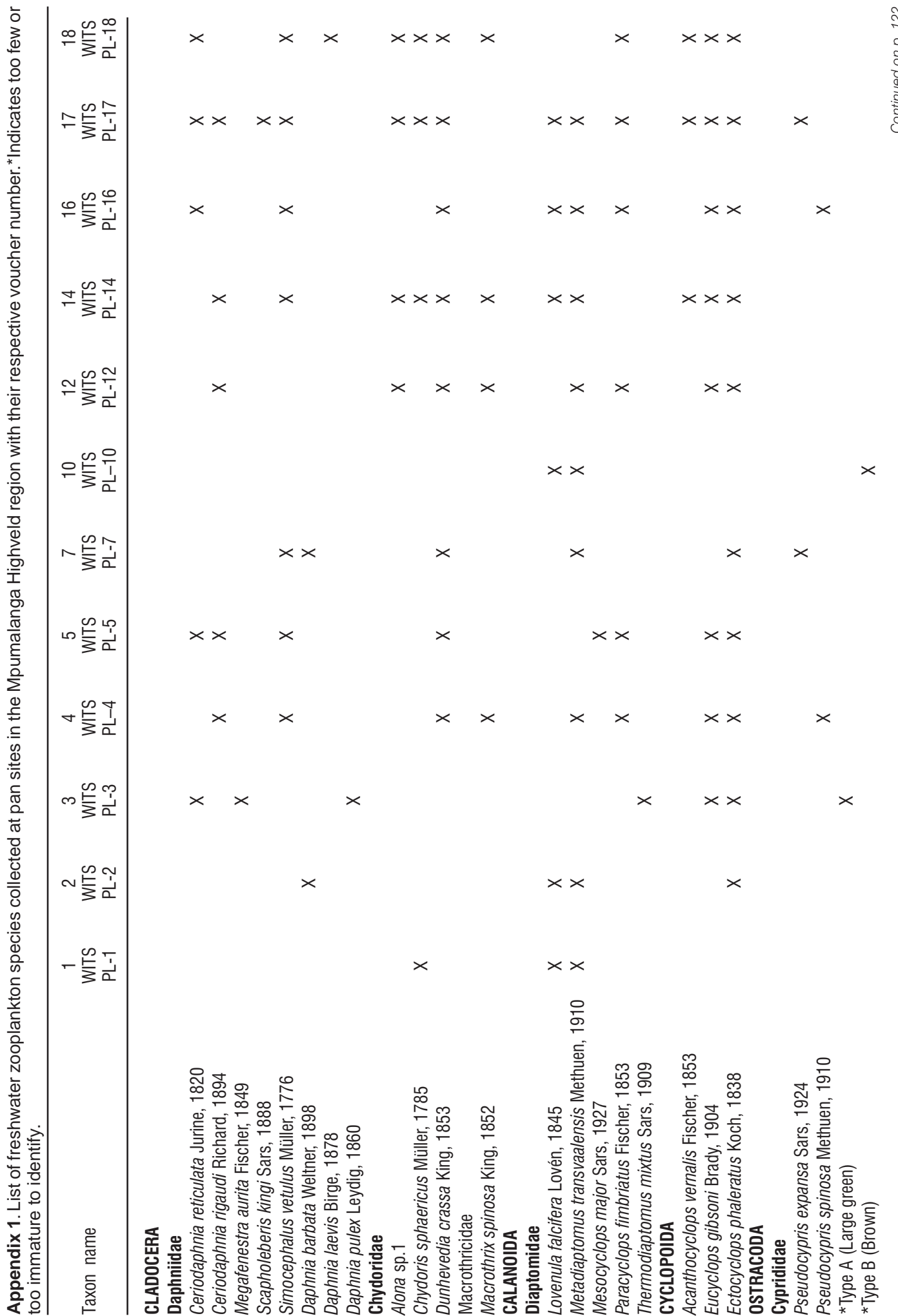




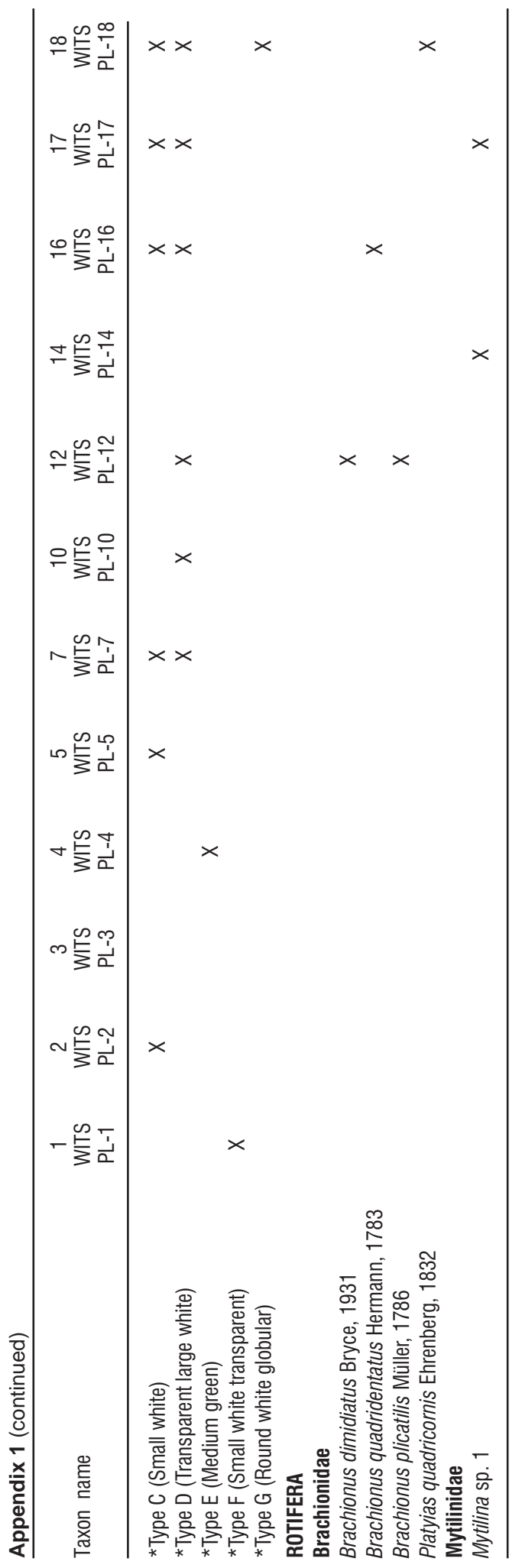


Riato et al.: Zooplankton and diatoms of freshwater pans in Mpumalanga

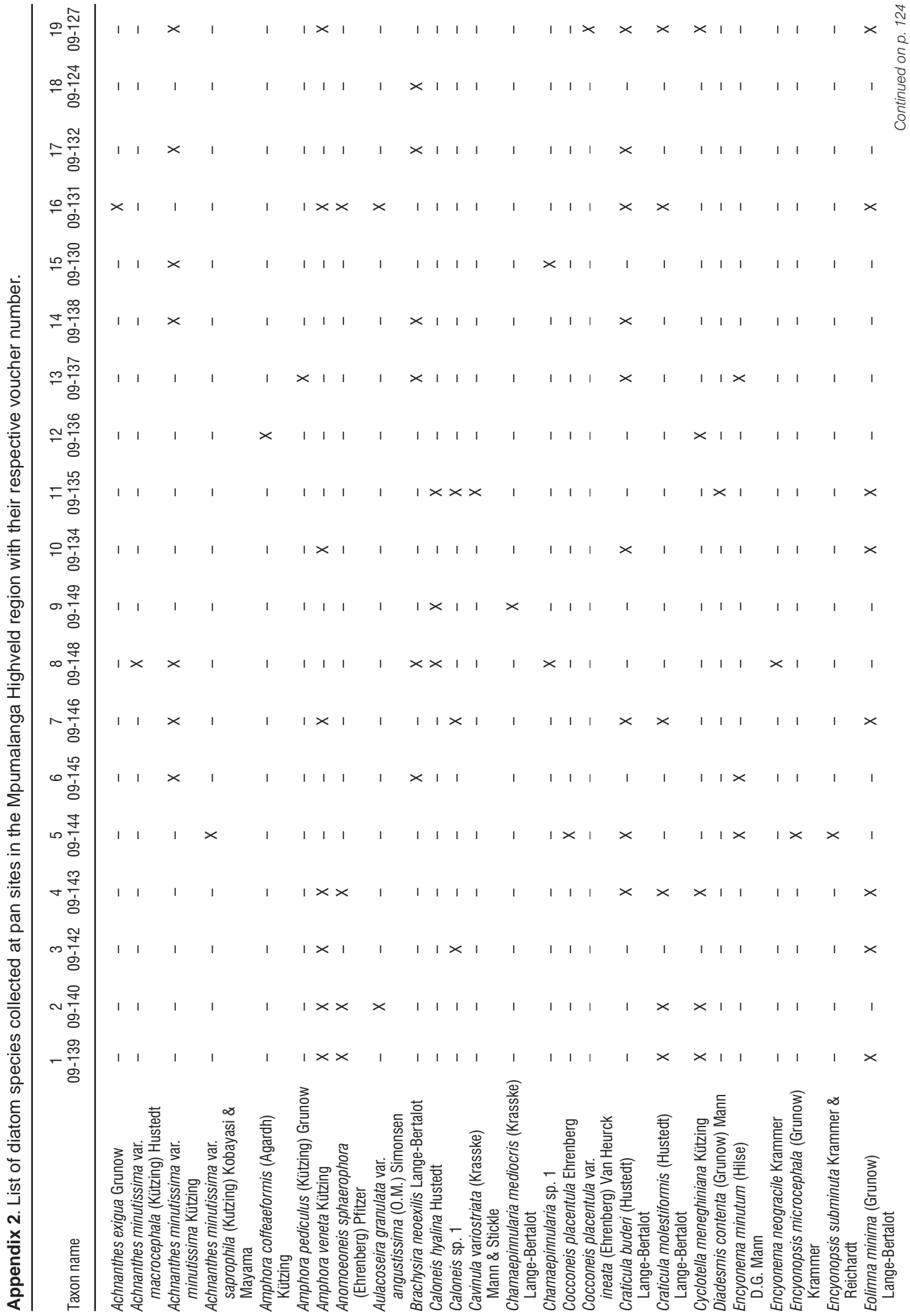




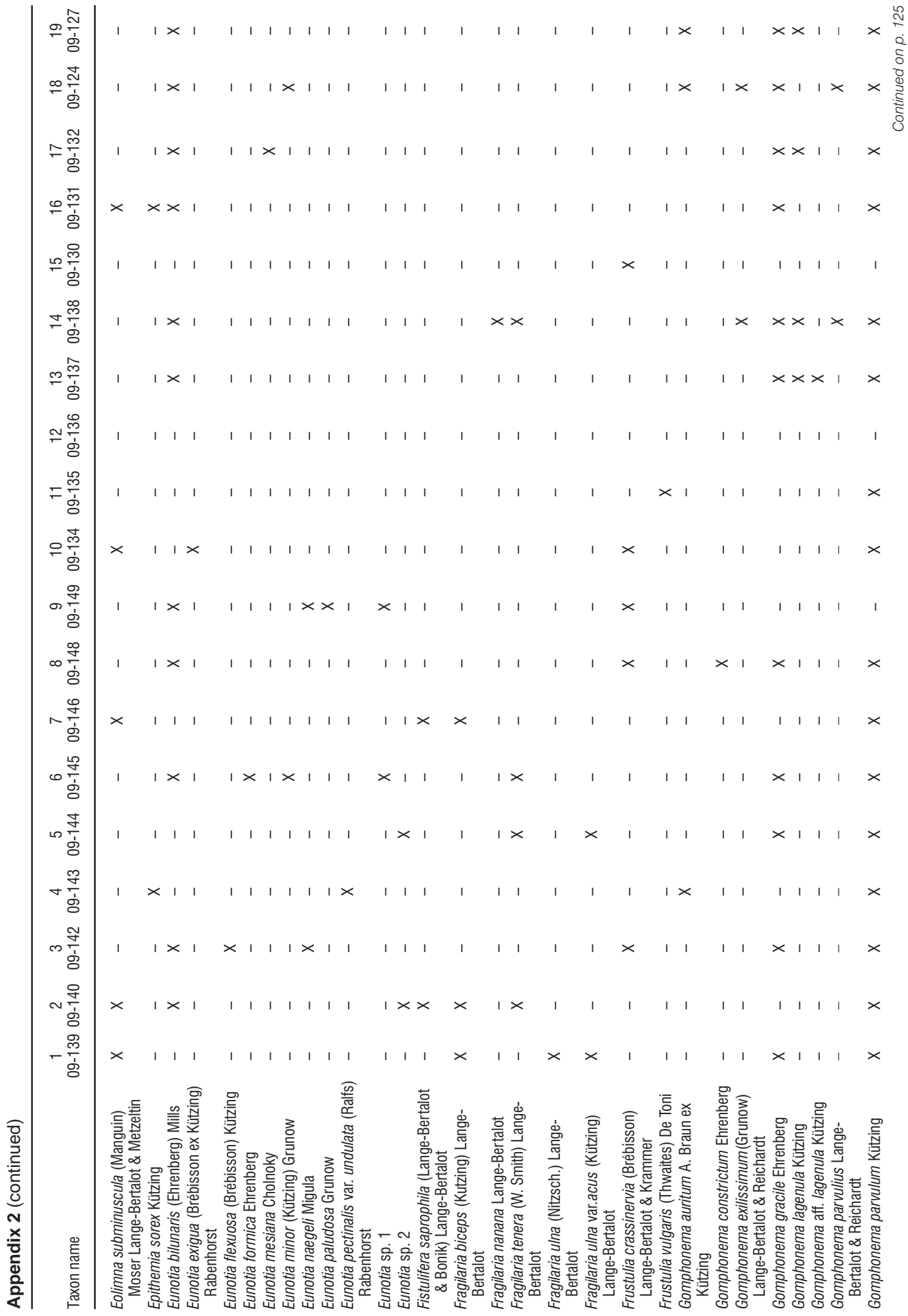




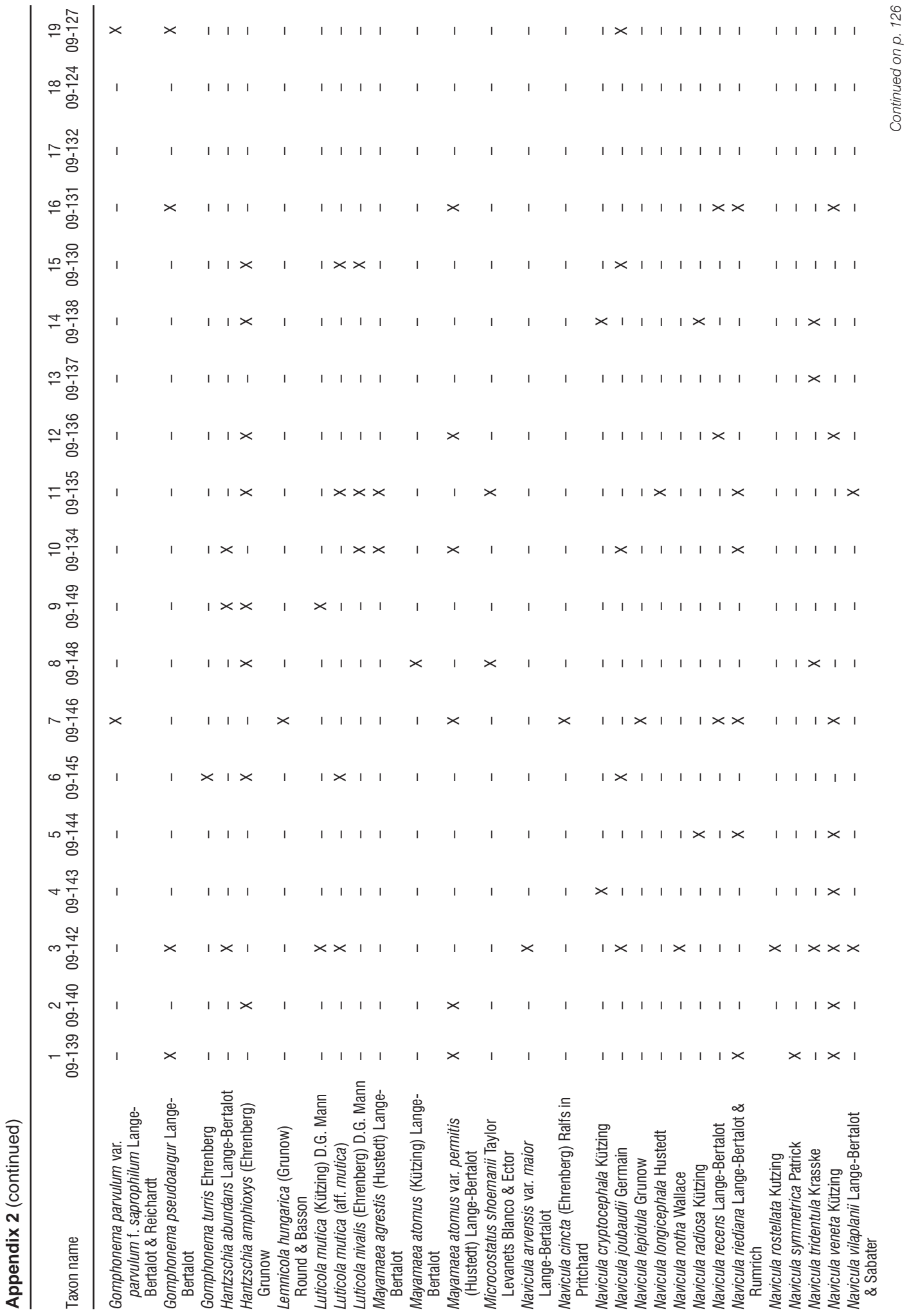




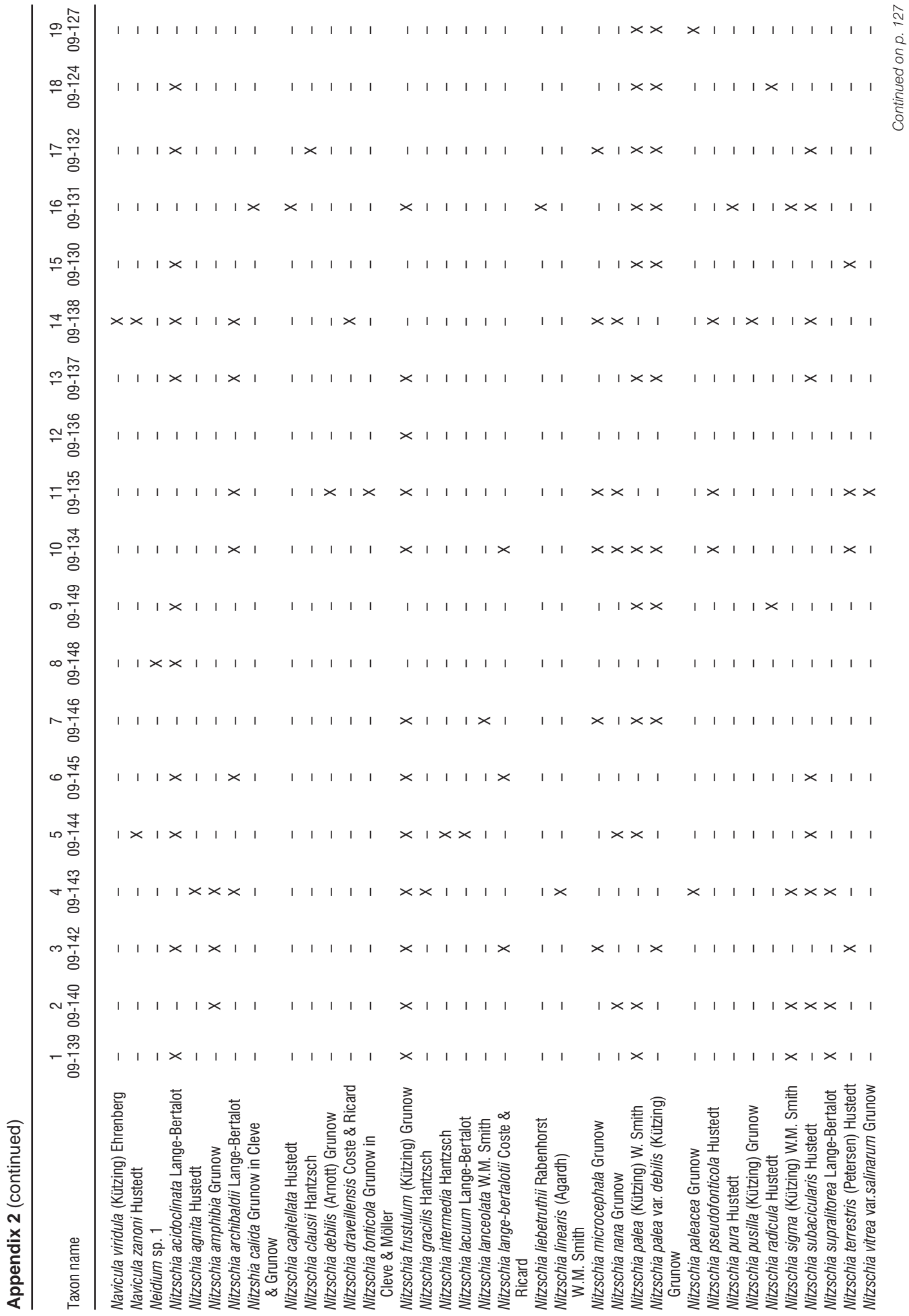


Riato et al.: Zooplankton and diatoms of freshwater pans in Mpumalanga

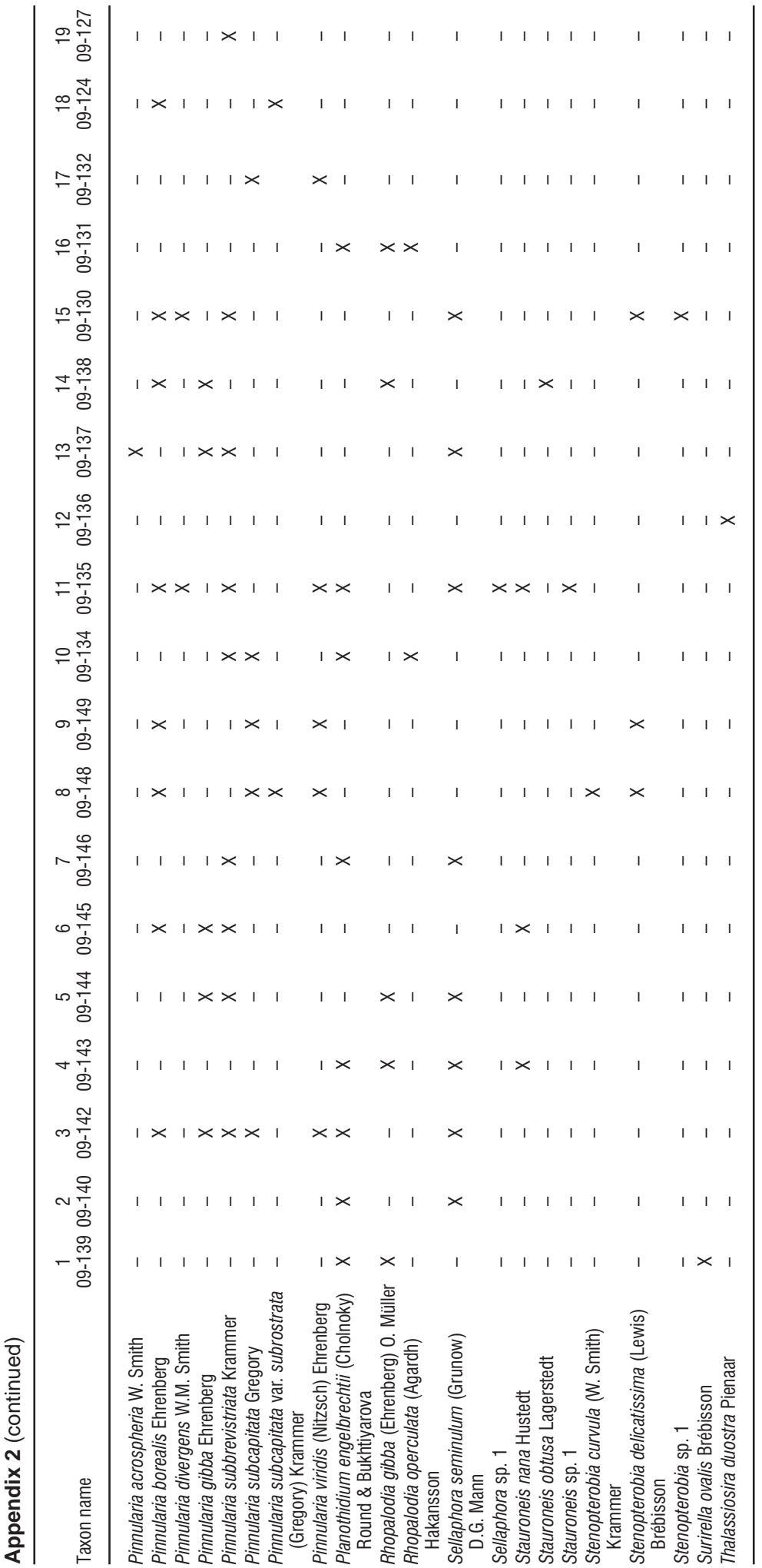

